\title{
EFEKTIVITAS PEMBELAJARAN ETIKA PROFESI DENGAN MENGGUNAKAN METODE DISKUSI MELALUI APLIKASI WHATSAPP
}

\section{Suri Triwahyuni}

Sekolah Menengah Kejuruan Negeri 1 Singkep Riau, Indonesia

Email: suritriwahyuni@gmail.com3

\begin{abstract}
This research aims to improve the effectiveness of students in receiving Professional Ethics lessons by applying discussion methods through whatsapp application assisted with powerpoint media, so that students' learning outcomes achieve the expected goals. This research was conducted at SMK Negeri 1 Singkep. The research used is class action research, which consists of pretest and postest. Success indicators can be seen from the evaluation of assessments on the I and test II tests. The results of the study using the discussion method through whatsapp application assisted with powerpoint media showed that students who achieved the Minimum Completion Criteria (KKM) were $91 \%$ and that were not complete $9 \%$. While the response of learners to the effectiveness of professional ethics learning professional ethics learning using the method of discussion through the WhatsApp application assisted by powerpoint media $97 \%$ and the implementation of discussions by $91 \%$ with the ratio of interaction between groups to comment on each other by 5. Based on this research, it can be concluded that the learning of Professional Ethics by using discussion method through WhatsApp application assisted by powerpoint media in grade $X$ students of SMK Negeri 1 Singkep banking year 2020/2021 has been very effective based on the learning outcomes of learners, and student responses.
\end{abstract}

Keywords: Professional Ethics; discussion methods; WhatsApp application; and powerpoint media

\footnotetext{
Abstrak

Penelitian ini bertujuan untuk meningkatkan keefektivitas siswa dalam menerima pelajaran Etika Profesi dengan penerapan metode diskusi melalui aplikasi whatsapp berbantuan dengan media powerpoint, sehingga hasil belajar siswa mencapai tujuan yang diharapkan.. Penelitian ini dilakukan di SMK Negeri 1 Singkep. Penelitian yang digunakan adalah penelitian tindakan kelas, yang terdiri dari pretest dan postest. Indikator keberhasilan dapat dilihat dari evaluasi penilaian pada tes I dan tes II. Hasil penelitian dengan menggunakan metode diskusi melalui aplikasi whatsapp berbantuan dengan media powerpoint menunjukkan peserta didik yang mencapai Kriteria Ketuntasan Minimal (KKM) adalah 91\% dan yang tidak tuntas 9\%. Sedangkan tanggapan peserta didik terhadap keefektifan pembelajaran Etika Profesi pembelajaran Etika Profesi dengan menggunakan metode diskusi melalui aplikasi WhatsApp berbantuan media powerpoint 97\% dan keterlaksanaan diskusi sebesar 91\% dengan rasio interaksi antar kelompok untuk saling mengomentari sebesar 5. Berdasarkan penelitian ini, dapat disimpulkan pembelajaran Etika Profesi
} 
dengan menggunakan metode diskusi melalui aplikasi WhatsApp berbantuan media powerpoint pada siswa kelas X Perbankan SMK Negeri 1 Singkep tahun pelajaran 2020/2021 sudah sangat efektif berdasarkan hasil belajar peserta didik, dan tanggapan peserta didik.

Kata kunci: etika profesi; metode diskusi; aplikasi WhatsApp; dan media powerpoint

\section{Pendahuluan}

Semakin tinggi kesadaran masyarakat untuk mencapai tingkat pendidikan yang lebih tinggi dan berkualitas mendorong perguruan tinggi untuk menyiapkan sumber daya tersebut sehingga mampu bersaing secara sehat di dunia pekerjaan nantinya (Nurkarsa, 2020).

Pendidikan sebagai sebuah kegiatan dan proses aktivitas yang disengaja merupakan gejala masyarakat ketika sudah mulai disadari pentingnya upaya untuk membentuk, mengarahkan, dan mengatur manusia sebagaimana dicita-citakan masyarakat (Gunawan, 2012).

Pendidikan merupakan harapan dan cita cita luhur bagi para pemimpin bangsa ini khususnya untuk orang tua. Selain itu pendidikan merupakan hal yang penting dalam kehidupan seseorang terlebihuntuk menghadapi persaingan dan kompetisi global yang semakin tinggi memaksa setiap individu untuk lebih cerdas dalam menyikapi hal tersebut guna memenuhi kebutuhan hidupnya. Atas dasar itulah, maka seseorang dituntut untuk meningkatkan kualitas hidupnya melalui pendidikan agar dapat bersaing dan berkompetensi secara global (Mukson, 2017).

Pendidikan sebagai proses belajar mengajar merupakan suatu hal yang paling actual, menarik dan yang paling hangat dibicarakan sepanjang zaman bahkan sampai sekarang Pendidikan sendiri merupakan suatu proses yang memerlukan perhatian banyak orang, tidak hanya guru sebagai pendidik bahkan peran orang tua, serta peserta didik perlu diperhatikan oleh berbagai pihak guna meningkatkan kehidupan yang semakin maju ini (Khoriah, 2020).

Kegiatan belajar mengajar adalah suatu kondisi yang dengan sengaja diciptakan. Guru atau tutorlah yang menciptakannya guna membelajarkan siswa atau peserta didik. Tutor yang mengajar dan peserta didik yang belajar (Afandi, Chamalah, Wardani, \& Gunarto, 2013).

Mengajar merupakan tugas utama seorang pendidik (guru, dosen, tutor, instruktur, widyaiswara). Pendidik yang kreatif akan selalu menciptakan ide-ide dalam merancang sistem pembelajaran baru yang mampu membuat peserta didik dapat mencapai tujuan belajarnya dengan penuh rasa puas. Untuk memperoleh sistem pembelajaran baru tersebut diperlukan metode penelitian dan pengembangan sistem pembelajaran. Metode pengembangan sistem pembelajaran tidak jauh berbeda dengan metode pengembangan produk lainnya (Mulyatiningsih, 2016).

Metode pembelajaran sangat dibutuhkan dalam sekolah, khususnya bagi pembelajaran di dalam kelas. (Trianto, 2010) menyebutkan bahwa model pembelajaran adalah suatu perencanaan atau pola yang digunakan sebagai pedoman dalam 
merencanakan pembelajaran di kelas atau pembelajaran tutorial. (Sutikno \& Fathurrohman, 2010) berpendapat makin tepat metode yang digunakan oleh guru dalam mengajar, diharapkan makin efektif pula pencapaian tujuan pembelajaran.

Saat ini metode pembelajaran tatap muka antara guru dan peserta didik masih dilakukan secara bergantian. Akan tetapi pembelajaran tatap muka tidak cukup untuk membahas materi yang diberikan. Hal ini ditandai banyaknya waktu tatap muka pembelajaran yang tidak efektif karena berlakunya new normal pada masa pandemi Covid-19. Pada akhirnya ada beberapa materi yang belum sempat disampaikan akibat tatap muka yang dilakukan guru dan waktu peserta didik yang terpotong pada akhirnya peserta didik merasa belum mampu atau belum mengerti dengan materi yang diajarkan karena pada saat dijelaskan guru terpaku dengan waktu. Jika hanya mengandalkan pembelajaran tatap muka di kelas tentu tidak efisien dan efektif, karena peserta didik harus berkonsultasi dengan guru untuk membahas materi tersebut tidak sekedar mencatat atau memfotokopi file.

Salah satu dampak pandemi Coronavirus 2019-20 ialah terhadap pendidikan di seluruh dunia, yang mengarah kepada penutupan luas sekolah, madrasah, universitas, dan pondok pesantren. Kami turut merasakan dampak tersebut berupa perubahan pelaksanaan pembelajaran di madrasah dan pondok pesantren. Rekan kami, Surotul Ilmiyah, yang sedang mengambil studi doktoral di Xiangya School of Public Health, Central South University (CSU), Changsha, Hunan, China, sampai saat ini belum bisa kembali ke universitas. UNESCO (United Nations Educational, Scientific and Cultural Organization) pada 4 Maret 2020 menyarankan penggunaan pembelajaran jarak jauh dan membuka platform pendidikan yang dapat digunakan sekolah dan guru untuk menjangkau peserta didik dari jarak jauh dan membatasi gangguan Pendidikan (Lembar Pembelajaran Jarak Jauh, 2020).

Untuk mengatasi hal tersebut, pembelajaran jarak jauh atau daring menjadi salah satu solusi yang tepat pada saat ini. Hal ini dikarenakan pembelajaran jarak jauh bisa dilakukan tanpa pembelajaran tatap muka di kelas. Selain itu juga, pembelajaran jarak jauh bisa dilakukan kapanpun oleh guru dan peserta didik ingin lakukan. Dalam pembelajaran jarak jauh juga guru dan peserta didik dapat berdiskusi tanpa harus mengenal waktu dan peserta didikpun dapat menyuarakan pendapatnya. Seperti yang kita ketahui banyak peserta didik ketika guru sedang menjelaskan mereka berdiam diri atau tidak berbicara antara mereka takut dan mereka malu untuk menyuarakan pendapat mereka.

Berdasarkan perkembangan zaman masa new normal dan untuk memutuskan penyebaran Covid-19 banyak sekali perubahan yang kita rasakan, terutama dalam proses pembelajaran dari tatap muka berganti dengan pembelajaran jarak jauh atau daring. Begitu juga dengan jejaring sosial yang semakin pesat dan semakin mengalami perubahan dari tahun ke tahun. Bahkan tidak banyak pula peserta didik yang menggunakan jejaring sosial untuk kegiatan positif dan negatif. Padahal dengan adanya jejaring sosial peserta didik dapat mendapatkan informasi dari segala bentuk hal yang bisa membuat siswa menambah wawasan (hifzul Muiz \& Sumarni, 2020). 
Sekarang telah banyak jejaring sosial yang dapat membantu siswa untuk mengatasi efektivitas belajar mereka dan membuat belajar peserta didik menjadi mudah. Salah satu jejaring yang bisa dimanfaatkan oleh peserta didik adalah aplikasi WhatsApp. Aplikasi WhatsApp merupakan jejaring sosial yang berbentuk sosial media pribadi berbasis internet dan mengutamakan privasi. Sehingga peserta didik dapat mengakses bahan ajar yang disediakan oleh guru sesuai dengan materi yang diajarkan, latihan soal, powerpoint, dan video pembelajaran. Jejaring sosial ini berbasis online sehingga dapat didownload di laptop dan di hanphone dengan mencarinya di googleplay. Dari hasil observasi pada pembelajaran tatap muka bahwa seluruh peserta didik memiliki hanphone android. Sehingga mayoritas peserta didik seluruhnya sudah memiliki handphone.

Di dalam pembelajaran berbasis aplikasi WhatsApp guru bukan hanya mengakses materi dalam bentuk word saja melainkan dapat mengakses powerpoint, dan video pembelajaran. Media pembelajaran yang efektif merupakan media yang mencakup daya serap melalui pengelihatan dan pendengaran, salah satunya dengan media pembelajaran berbentuk slide ataupun video. Pernyataan ini didukung oleh (Arsyad, 2014) mengatakan bahwa media pembelajaran meliputi alat yang secara fisik digunakan untuk menyampaikan isi materi pengajaran, yang terdiri dari antara lain buku, tape recorder, film, slide, foto, gambar, grafik, televisi, dan komputer.

Aplikasi WhatsApp berbantuan media powerpoint bisa diakses oleh semua guru dan peserta didik kapanpun dan dimanapun sehingga membuat peserta didik tidak mengalami kesulitan dalam proses Pembelajaran karena media ini dapat diakses diluar jam sekolah maupun pada jam sekolah sebab Aplikasi WhatsApp berbantuan media powerpoint dapat diakes di rumah atau pun di luar rumah. Untuk metode, guru masih menggunakan metode diskusi dalam penyampaian materi, adapun alasan kenapa guru menggunakan metode dan media pembelajaran ini untuk mengatasi kejenuhan peserta didik ketika belajar daring dan untuk keaktifan peserta didik terhadap pembelajaran ini (Rosyidah \& Maryati, 2019).

Aplikasi WhatsApp adalah media pembelajaran yang berbasis online yang berbentuk seperti facebook. Media ini dapat memudahkan peserta didik dan guru dalam proses pembelajaran secara daring seiring dengan waktu perkembangan zaman (Rismiyanti, 2012). Dapat disimpulkan bahwa Aplikasi WhatsApp berfungsi sebagai perantara penugasan dan interaksi antara guru dan peserta didik, sehingga Aplikasi WhatsApp memungkinkan untuk diterapkan sebagai penunjang pembelajaran.

Penerapan media pembelajaran melalui aplikasi WhatsApp banyak digunakan oleh guru untuk meningkatkan efektifitas belajar dan hasil belajar peserta didik dikelas dan mengatasi keterbatasan tatap muka di kelas selama new normal dan mengurangi rasa kebosanan peserta didik. Dilihat dari segi tampilannya, aplikasi WhatsApp memiliki tampilan yang menarik dan mudah digunakan oleh guru dan peserta didik. Tujuan penerapan aplikasi WhatsApp adalah sebagai media pembelajaran yang diimplementasikan kepada peserta didik untuk menunjang proses pembelajaran dan meningkatkan efektifitas belajar peserta didik (Silmi, 2021). Sedangkan tujuan 
penerapan metode diskusi dalam pembelajaran daring untuk menumbuhkan keberanian dan rasa percaya diri peserta didik untuk menyampaikan pendapatnya dalam belajar.

Untuk mengoptimalkan pembelajaran jarak jauh atau daring perlu adanya kegiatan yang memanfaatkan berbagai metode, aplikasi dan media pembelajaran antara lain metode diskusi melalui aplikasi WhatsApp berbantuan dengan media powerpoint agar tujuan pembelajaran tercapai. Metode diskusi melalui aplikasi WhatsApp berbantuan media powerpoint dalam pembelajaran etika profesi sangat penting diterapkan dalam pembelajaran guna meningkatkan mutu pendidikan.

Rumusan masalah penelitian ini adalah bagaimanakah penerapan metode diskusi melalui aplikasi Whatsapp berbantuan dengan media Powerpoint untuk meningkatkan keefektifan pembelajaran Etika Profesi siswa kelas X Perbankan SMK Negeri 1 Singkep. Adapun tujuan penelitian ini adalah untuk meningkatkan keefektivitas siswa dalam menerima pelajaran Etika Profesi dengan penerapan metode diskusi melalui aplikasi whatsapp berbantuan dengan media powerpoint, sehingga hasil belajar siswa mencapai tujuan yang diharapkan.

Adapun hasil penelitian terdahulu yang relevan atau berhubungan dengan penelitian yang dilakukan oleh peneliti, yaitu sebagai berikut:

1. Hasil Penelitian (Putra, 2019). Melakukan penelitian yang berjudul "Penerapan Media Internet Untuk Mendukung Pembelajaran Pada Mata Pelajaran Etika Profesi Kelas X Akuntansi Di Smk Negeri 1 Singaraja.” Pada penelitian ini penerapan media internet dapat meningkatkan hasil belajar siswa pada mata pelajaran etika profesi. Hal ini dapat dilihat dari nilai rata-rata hasil belajar sebelum penerapan media internet yang diperoleh melalui pre-test sebesar 64,157, rata-rata sesudah penerapan media internet yang diperoleh dari post-test sebesar 75,842, dan nilai probabilitas $0,000<0,05$, maka ho ditolak, yang berarti hasil belajar siswa sebelum dan sesudah penerapan media internet adalah berbeda.

2. Hasil Penelitian Maharani Fadhiyah Haifani (2018), melakukan Penelitian yang berjudul "Penggunaan Media Edmodo Pada Mata Pelajaran Etika Profesi Untuk Efektifitas Belajar Siswa Kelas X Akuntansi Di Smk Negeri 1 Banyudono Tahun Pelajaran 2018/2019”. Dalam penelitian ini, peneliti menunjukkan hasil penilaian kelayakan media pembelajaran menggunakan Edmodo penilaian ashli materi diperoleh rata-rata 5,4 dan masuk kategori sangat layak. Penilaian ahli media diperoleh rata-rata 3,6 dan masuk dalam kategori layak. Sedangkan penliaian responden atau subjek uji coba produk diperoleh dengan rata rata 5,0 dan masuk dalam kategori sangat layak. Sehingga berdasarkan penilaian tersebut maka penggunaan media pembelajaran Edmodo memiliki kelayakan dan dapat digunakan dalam kegiatan pembelajaran.

\section{Metode Penelitian}

Penelitian tindakan kelas ini dilaksanakan di SMK Negeri 1 Singkep pada kelas X Perbankan dengan jumlah siswa 34 orang. Model yang digunakan pada tindakan ini adalah model siklus, dengan catatan bila hasil evaluasi belum menunjukkan 
keberhasilan pencapaian tujuan maka akan dilakukan refleksi dan revisi yang ditindaklanjuti dengan pelaksanaan tindakan siklus II. Proses pelaksanaan tindakan dalam kegiatan belajar mengajar pada siklus I (pretest) diuraikan sebagai berikut:

a. Kegiatan Pendahuluan (waktu 10 menit)

1. Guru menyiapkan siswa untuk menerima pelajaran melalui grup WhatsApp

2. Mengadakan apersepsi berupa pertanyaan-pertanyaan yang ada hubungan dengan pelajaran sebelumnya yang merupakan pengetahuan prasyarat mengenai pemahaman siswa mengenai sifat etika profesi dalam bidang Akuntansi

3. Memberikan motivasi untuk menumbuhkan semangat siswa dan membangkitkan minat mereka untuk melakukan metode belajar dengan diskusi.

4. Membagikan file PPT materi ajar Etika Profesi

5. Memberitahukan konsep dan tujuan metode diskusi

b. Kegiatan Inti (50 Menit)

1. Siswa membaca dan mempelajari file PPT dan cara kerja tugas yang diberikan dan kemudian melakukan aktivitas berpikir

2. Guru mengontrol dan memberikan arahan kepada siswa yang mengalami kesulitan dalam melaksanakan metode belajar diskusi.

3. Setiap kelompok mendiskusikan dan menjawab pertanyaan-pertanyaan yang ada dalam file PPT dengan melakukan aktivitas bertanya

4. Guru meminta masing-masing siswa untuk mengumpulkan tugas dan mempresentasikan hasil diskusinya di dalam grup WhatsApp secara bergiliran dengan siswa lain memperhatikan dan memberikan komentar

5. Guru membimbing siswa untuk membuat kesimpulan dari hasil diskusi.

c. Kegiatan penutup (waktu 30 menit)

1. Membimbing dan mengarahkan siswa untuk merangkum pelajaran.

2. Memberikan evaluasi test 5 soal untuk mengukur keberhasilan siswa.

3. Siswa mengerjakan soal.

4. Memberikan soal-soal pekerjaan rumah

Alat pengumpul data dalam penelitian ini adalah: a) Tes hasil belajar, b) Tes hasilKuisioner, dan c) Pedoman keterlaksanaan diskusi. Sedangkan kriteria untuk keberhasilan tujuan penelitian tindakan kelas ini dirumuskan sebagai berikut:

a. Kesediaan guru mengadakan refleksi secara jujur dan objektif tentang perlunya peningkatan kemampuan profesional diri dapat dilihat dari frekuensi pemanfaatan fasilitas supervisi dari pengamat sekurangkurangnya $80 \%$ dari seluruh KBM dapat dilaksanakan dengan baik, hasilnya berkualitas.

b. Evaluasi hasil belajar yang dicapai oleh siswa apabila :

1. Daya serap setiap peserta didik mencapai $85 \%$ memperoleh nilai baik dan amat baik. 
Keefektifan pembelajaran etika profesi dengan menggunakan metode diskusi

2. Daya serap klasikal, mencapai $85 \%$ mendapat nilai 65 pada ulangan formatif.

Data yang terkumpul adalah secara kuantitatif yaitu dengan memperhatikan hasil kuisioner tanggapan siswa dan hasil tes belajar siswa. Hasil analisis data ini sangat dibutuhkan untuk perlu tidaknya siklus berikutnya dilaksanakan.

\section{Hasil dan Pembahasan}

\section{A. Hasil}

Berdasarkan hasil penelitian tindakan kelas kurikulum 2013 dengan menggunakan metode diskusi melalui aplikasi whatsapp berbantuan dengan media power point diperoleh data sebagai berikut :

1. Tahap Awal

a. Dalam pelaksanaan metode diskusi melalui aplikasi whatsapp berbantuan dengan media power point pada pemahaman konsep materi Etika Profesi, masih ada sebagian besar siswa mengalami kesulitan karena belum mengenal langkah-langkah penerapan metode yang digunakan dalam pembelajaran daring.

b. Siswa masih mengalami kesulitan dalam pengisian tes dan kuesioner, dan pada waktu diskusi masih didominasi oleh siswa-siswa tertentu, hal ini dikarenakan siswa sudah terbiasa dengan metode-metode sebelumnya, yaitu ceramah dimana siswa kurang diberi kesempatan untuk mengemukakan pendapatnya, sehingga hasil yang diperoleh masih dibawah dari yang diharapkan. Hal ini juga karena penggunaan metode diskusi melalui aplikasi whatsapp berbantuan dengan media power point merupakan hal yang baru bagi siswa sehingga dalam pelaksanaannya masih banyak siswa yang harus menyesuaikan diri dengan metode diskusi berbasis android.

c. Sesuai hasil informasi balikan sebaiknya guru secara kontinyu membantu dan membimbing siswa yang mengalami kesulitan pada saat melakukan metode diskusi melalui aplikasi whatsapp berbantuan dengan media power point dalam pengisian tes dan kuesioner.

d. Penggunaan aplikasi whatsapp berbantuan dengan media power point yang divariasikan dengan metode diskusi sangat mendukung dalam kegiatan proses belajar mengajar.

e. Dalam informasi balikan siswa menyarankan agar powerpoint dibagikan seminggu sebelum pelaksanaan metode diskusi supaya dapat dipelajari tujuan dan cara kerja yang ada dalam tes.

Data hasil penelitian yang diperoleh adalah sebagai berikut:

1. Data Keterlaksanaan Diskusi

Data keterlaksanaan diskusi diperoleh melalui proses saat menggunakan aplikasi WhatsApp untuk diskusi materi dan latihan soal. Data keterlaksanaan diskusi dilihat melalui beberapa aspek, seperti persentase peserta didik yang 
mengumpulkan latihan soal, rasio interaksi peserta didik saat berdiskusi, dan kualitatif dari komentar- komentar yang diberikan.

Data Tes Hasil Belajar Peserta Didik

Data tes hasil belajar peserta didik diperoleh melalui tes yang dilakukan setelah semua rangkaian pembelajaran selesai. Data Tanggapan Peserta Didik Tentang Penggunaan WhatsApp. Tanggapan peserta didik terhadap keefektifan pembelajaran Etika Profesi dengan menggunakan metode diskusi melalui aplikasi WhatsApp berbantuan media powerpoint diperoleh melalui lembar kuesioner. Wawancara dilakukan kepada guru dan beberapa peserta didik sedangkan lembar kuesioner diberikan hanya kepada peserta didik. Berikut adalah rangkuman tanggapan peserta didik. Berikut analisis data hasil penelitian:

1) Analisis Data Keterlaksanaan Diskusi

Berdasarkan aspek-aspek pada data keterlaksanaan diskusi yang dilakukan melalui aplikasi WhatsApp diperoleh:

a. Persentase peserta didik yang mengumpulkan latihan soal

Pada latihan tes I masing-masing peserta didik mengerjakan latihan soal yang diberikan sehingga secara keseluruhan terdapat 24 dari 34 peserta didik yang mengumpulkan latihan soal. Hasil persentase peserta didik yang mengumpulkan latihan soal diperoleh bahwa persentase peserta didik yang mengumpulkan sebesar $70 \%$ sedangkan yang tidak mengumpulkan sebesar $30 \%$. Pada latihan tes II peserta didik mengerjakan latihan soal yang diberikan secara berkelompok. Terdapat 7 kelompok dan persentase keseluruhan peserta didik dalam kelompok mengumpulkan sebesar $91 \%$ sedangkan yang tidak mengumpulkan sebesar $9 \%$.

b. Rasio interaksi peserta didik saat berdiskusi

Rasio interaksi peserta didik diperoleh dengan total komentar seluruhnya per total peserta didik yang mengumpulkan latihan soal. Pada latihan test I total komentar seluruhnya sebesar 15 komentar dari 24 peserta didik sehingga rasionya apabila dibulatkan hasilnya sebesar 1. Pada latihan tes II total komentar seluruhnya sebesar 32 komentar dari 7 kelompok sehingga rasionya sebesar 5 .

c. Kualitatif dari komentar-komentar yang diberikan

Komentar-komentar yang diberikan oleh peserta didik kepada perintah guru berupa tanggapan positif terhadap absensi, pemahaman materi, pengerjaan tugas serta pengumpulan tugas dengan pernyataan setuju.

2) Analisis Data Hasil Penelitian, sebagai berikut:

1. Analisis Data Tes Hasil Belajar Peserta Didik

Berdasarkan data tes hasil belajar peserta didik hasil nilai tersebut kemudian diberi keterangan tuntas atau tidak tuntas sesuai dengan KKM yang ditetapkan $(\mathrm{KKM}=65)$. Dari data tersebut diperoleh bahwa peserta didik 
Keefektifan pembelajaran etika profesi dengan menggunakan metode diskusi

yang tuntas sebanyak 31 peserta didik dengan persentase sebesar $91 \%$ sedangkan yang tidak tuntas sebanyak 3 peserta didik dengan persentase sebesar 9\%. Selanjutnya, nilai yang diperoleh peserta didik tersebut dikelompokkan dengan merujuk untuk memperoleh kriteria efektivitas hasil belajar kemudian diperoleh bahwa secara keseluruhan hasil belajar peserta didik termasuk dalam kriteria efektivitas sangat tinggi.

2. Analisis Data Tanggapan Peserta Didik Tentang Penggunaan WhatsApp

Tanggapan peserta didik terhadap keefektifan pembelajaran Etika Profesi pembelajaran Etika Profesi dengan menggunakan metode diskusi melalui aplikasi WhatsApp berbantuan media powerpoint diperoleh melalui lembar kuesioner kepada beberapa peserta didik. Lembar kuesioner dibagikan di kelas setelah peserta didik selesai mengikuti pembelajaran dengan menggunakan metode diskusi melalui aplikasi WhatsApp berbantuan media powerpoint.

Pengisian lembar kuesioner ini diikuti oleh 31 peserta didik. Akan tetapi, pada pengambilan data tes hasil belajar terdapat 2 peserta didik yang tidak mengikuti tes tersebut sehingga pada analisis data kuesioner ini peneliti hanya menganalisis data dari peserta didik yang mengikuti pengisian kuesioner dan tes hasil belajar. Kuesioner berisi 20 pernyataan yang akan dijawab dengan sangat setuju, setuju, tidak setuju dan sangat tidak setuju. Kuesioner terdiri dari 10 pernyataan positif dan 10 pernyataan negatif. Kuesioner tidak diberikan melalui fitur chatting pada aplikasi WhatsApp karena adanya kemungkinan tidak semua peserta didik akan menjawab. Peneliti ingin mengetahui tanggapan peserta didik karena metode tersebut belum pernah digunakan oleh guru. Data kuesioner tersebut diperoleh melalui proses skoring, setelah itu dihitung persentase dari masing-masing peserta didik. Hasil persentase tersebut kemudian dikategorikan dan dianalis, secara keseluruhan tanggapan peserta didik terhadap keefektifan pembelajaran Etika Profesi pembelajaran Etika Profesi dengan menggunakan metode diskusi melalui aplikasi WhatsApp berbantuan media powerpoint yaitu sebanyak 3\% rendah, sedang $3 \%$, 62\% tinggi dan 32\% sangat tinggi. Hasil persentase tersebut kemudian dikategorikan diperoleh bahwa secara keseluruhan tanggapan peserta didik terhadap keefektifan pembelajaran Etika Profesi pembelajaran Etika Profesi dengan menggunakan metode diskusi melalui aplikasi WhatsApp berbantuan media powerpoint termasuk dalam kategori tinggi.

Selanjutnya peneliti menghitung persentase dari masing- masing aspek pada kuesioner tersebut. Hasil persentase tersebut kemudian dikategorikan diperoleh bahwa aspek minat dan aspek penggunaan masuk dalam kategori sangat tinggi dengan persentase masing-masing aspek sebesar $93,25 \%$ dan $94,17 \%$.

Pembelajaran dengan memanfaatkan aplikasi WhatsApp berbantuan media powerpoint juga memiliki kelebihan, yaitu: lebih fleksibel waktu dan tempat, mendapatkan materi pembelajaran lebih banyak, mengumpulkan tugas-tugas menjadi mudah, dan bisa mengganti pertemuan di kelas. Selain kelebihan terdapat pula beberapa 
kekurangan seperti jaringan atau server yang error. Akan tetapi, untuk pembelajaran selanjutnya diharapkan pembelajaran seperti ini dapat diterapkan lagi agar lebih mudah mengumpulkan tugas-tugas waktu untuk mengakses WhatsApp berbantuan media powerpoint saat diskusi lebih lama, dan aplikasinya dikembangkan tidak hanya untuk memfasilitasi diskusi saja tetapi bisa juga untuk ujian atau kuis.

\section{B. Pembahasan}

Pembahasan dibagi dalam beberapa bahasan, yaitu keterlaksanaan diskusi, keefektifan pembelajaran Etika Profesi dengan menggunakan metode diskusi melalui aplikasi WhatsApp berbantuan media powerpoint ditinjau dari hasil belajar peserta didik, tanggapan dari peserta didik, dan hambatan-hambatan yang dialami.

1. Keterlaksaan Diskusi

Berdasarkan analisis data yang diperoleh, keterlaksanaan diskusi yang dilakukan melalui aplikasi WhatsApp berbantuan media powerpoint pada latihan tes I persentase peserta didik yang mengumpulkan latihan soal sebesar $70 \%$ dengan rasio interaksi antar peserta didik untuk saling mengomentari sebesar 1 . Hal ini dapat diartikan bahwa secara keseluruhan setiap peserta didik yang menggunggah hasil pekerjaannya terdapat 1 interaksi yang terjadi antar peserta didik terhadap hasil pekerjaan tersebut. Pada latihan tes II persentase kelompok yang mengumpulkan latihan soal sebesar 91\% dengan rasio interaksi antar kelompok untuk saling mengomentari sebesar 5. Hal ini dapat diartikan bahwa secara keseluruhan setiap kelompok yang menggunggah hasil pekerjaannya terdapat 5 interaksi yang terjadi antar kelompok terhadap hasil pekerjaan tersebut. Interkasi yang berupa komentar-komentar yang diberikan pada latihan tes I dan latihan tes II kurang lebih sama, yaitu peserta didik kepada perintah guru berupa tanggapan positif terhadap absensi, pemahaman materi, pengerjaan tugas serta pengumpulan tugas dengan pernyataan setuju. Pada latihan tes I dan latihan tes II apabila dilihat secara keseluruhan persentase peserta didik yang mengumpulkan sudah tinggi, rasio interaksi yang dilakukan juga relatif tinggi serta kualitatif dari komentar-komentar yang diberikan mengarah pada penyelesaian dari latihan soal yang diberikan sehingga dapat dikatakan bahwa aspek-aspek pada keterlaksaan diskusi sudah terpenuhi dan diskusi yang dilakukan melalui aplikasi WhatsApp berbantuan media powerpoint dapat terlaksana.

2. Hasil Belajar Peserta Didik

Berdasarkan analisis data yang diperoleh, secara keseluruhan persentase hasil belajar peserta didik yang tuntas sebesar $91 \%$ sedangkan peserta didik yang tidak tuntas (belum mencapai KKM) sebesar 9\%. Hal ini berarti keefektifan pembelajaran Etika Profesi dengan menggunakan metode diskusi melalui aplikasi WhatsApp berbantuan media powerpoint tidak mengganggu hasil belajar peserta didik. Selain itu untuk mengetahui keefektifannya, secara keseluruhan, hasil belajar peserta didik berada pada kriteria efektivitas sangat 
tinggi dengan persentase sebesar 54\%. Hal ini berarti keefektifan pembelajaran Etika Profesi dengan menggunakan metode diskusi melalui aplikasi WhatsApp berbantuan media powerpoint sudah sangat efektif.

Dari hasil ini, ada dugaan dari peneliti bahwa perbedaan hasil tes belajar peserta didik tersebut berkaitan dengan adanya pemanfaatan penggunakan metode diskusi melalui aplikasi WhatsApp berbantuan media powerpoint pada pembelajaran Etika Profesi.

Adanya fasilitas pembelajaran di luar kelas untuk melakukan kegiatan diskusi latihan soal membantu peserta didik agar lebih siap ketika mengerjakan tes sehingga hasil yang diperoleh pun menjadi lebih baik dan jumlah peserta didik yang belum mencapai KKM berkurang. Akan tetapi, peneliti belum dapat memastikan peserta didik yang belum mencapai KKM bisa jadi mengalami kendala seperti keterbatasan dalam mengakses WhatsApp karena jaringan atau server yang error saat mengakses sehingga peserta didik tersebut tidak dapat mengakses WhatsApp berbantuan media powerpoint dengan optimal.

3. Tanggapan Peserta Didik

Berdasarkan analisis data yang diperoleh, secara keseluruhan tanggapan peserta didik terhadap keefektifan pembelajaran Etika Profesi dengan menggunakan metode diskusi melalui aplikasi WhatsApp berbantuan media powerpoint termasuk dalam kategori tinggi dengan persentase sebesar $97 \%$. Secara keseluruhan, tanggapan peserta didik berada pada kriteria efektivitas tinggi dengan persentase sebesar 62\%. Oleh karena itu, tanggapan peserta didik terhadap keefektifan pembelajaran Etika Profesi dengan menggunakan metode diskusi melalui aplikasi WhatsApp berbantuan media powerpoint adalah baik atau efektif.

Keefektifan tersebut dilihat dari setiap aspek yang digunakan untuk menyusun pernyataan pada setiap kuesioner. Aspek-aspek tersebut yaitu aspek minat dan aspek penggunaan. Aspek minat dilihat dari perasaan peserta didik dan ketertarikan peserta didik mengikuti pembelajaran Etika Profesi dengan menggunakan metode diskusi melalui aplikasi WhatsApp berbantuan media powerpoint. Sedangkan aspek penggunaan dilihat dari pengalaman peserta didik, keterlibatan peserta didik dan pandangan peserta didik dalam mengikuti pembelajaran Etika Profesi dengan menggunakan metode diskusi melalui aplikasi WhatsApp berbantuan media powerpoint. Berdasarkan analisis data yang diperoleh, pada lampiran 13 aspek minat dan aspek penggunaan termasuk dalam kategori sangat tinggi dengan persentase masing-masing sebesar 93,25\% dan 94,17\%. Hal ini berarti dari aspek minat dan aspek penggunaan, pembelajaran Etika Profesi dengan menggunakan metode diskusi melalui aplikasi WhatsApp berbantuan media powerpoint sudah baik.

Selain itu, berdasarkan analisis per aspek pembelajaran Etika Profesi dengan menggunakan metode diskusi melalui aplikasi WhatsApp berbantuan media powerpoint lebih efektif, lebih praktis, dan efisien waktu, tempat dan biaya 
karena pembelajarannya dapat berlangsung secara fleksibel dimana saja dan kapan saja. Hal inilah yang menyebabkan pembelajaran ini mempunyai kelebihan, yaitu: mudah mengumpulkan tugas-tugas, mendapat materi lebih banyak dan dapat mengganti pertemuan di kelas pada masa new normal. Harapan pada pembelajaran selanjutnya, penggunaan aplikasi ini dapat diterapkan lagi agar lebih mudah mengumpulkan tugas-tugas, jaringan dikuatkan lagi agar tidak terjadi error, waktu untuk mengakses WhatsApp saat diskusi lebih lama, dan aplikasinya dikembangkan tidak hanya untuk memfasilitasi diskusi saja tetapi bisa juga untuk ujian atau kuis.

4. Hambatan-hambatan yang dialami

Pembelajaran Etika Profesi dengan menggunakan metode diskusi melalui aplikasi WhatsApp berbantuan media powerpoint tentu saja mengalami beberapa hambatan. Hambatan-hambatan yang dialami diketahui oleh peneliti melalui hasil belajar dan kuesioner peserta didik. Berdasarkan hasil belajar dan kuesioner tersebut hambatan yang dialami terkait dengan kekurangan aplikasi WhatsApp saat digunakan untuk berdiskusi, yaitu jaringan atau server terkadang error.

Penelitian tindakan kelas yang dilakukan oleh penulis tentang pembelajaran Etika Profesi dengan menggunakan metode diskusi melalui aplikasi WhatsApp berbantuan media powerpoint pada siswa kelas X Perbankan SMK Negeri 1 Singkep tahun pelajaran 2020/2021 sudah sangat efektif berdasarkan hasil belajar peserta didik, dan tanggapan peserta didik. Sedangkan penelitian kelas yang sudah pernah dilakukan dengan judul Penerapan Media Internet Untuk Mendukung Pembelajaran Pada Mata Pelajaran Etika Profesi Kelas X Akuntansi Di Smk Negeri 1 Singaraja diperoleh nilai rata-rata hasil belajar sebelum penerapan media internet yang diperoleh melalui pre-test sebesar 64,157, ratarata sesudah penerapan media internet yang diperoleh dari post-test sebesar 75,842 , dan nilai probabilitas $0,000<0,05$, maka ho ditolak, yang berarti hasil belajar siswa sebelum dan sesudah penerapan media internet adalah berbeda.

\section{Kesimpulan}

Berdasarkan hasil penelitian kelas dengan menerapkan metode diskusi melalui aplikasi WhatsApp berbantuan media powerpoint untuk meningkatkan keefektivitas pembelajaran Etika Profesi kelas X Perbankan, dapat disimpulkan bahwa penerapan metode, aplikasi, dan media tersebut dapat meningkatkan pemahaman siswa dalam belajar. Data peningkatan keefektifan dan kemampuan tersebut diperoleh berdasarkan nilai hasil belajar peserta didik yang mendapat nilai di atas KKM adalah $91 \%$ atau 31 peserta didik, sedangkan nilai yang dibawah KKM adalah 9\% atau 3 peserta didik, persentase tanggapan kategori tinggi adalah 97\% dan persentase tanggapan kategori rendah adalah $3 \%$ atau 1 peserta didik, dan persentase terlaksananya diskusi pada tes I peserta didik yang mengumpulkan latihan soal sebesar $70 \%$ dengan rasio interaksi antar peserta didik untuk saling mengomentari sebesar 1 dan pada tes II persentase kelompok 
yang mengumpulkan latihan soal sebesar 91\% dengan rasio interaksi antar kelompok untuk saling mengomentari sebesar 5. Jadi rasio keterlaksanaan diskusi $1: 5$.

Jadi secara keseluruhan hasil belajar peserta didik berada pada kriteria efektivitas sangat tinggi dengan persentase $54 \%$, dan tanggapan peserta didik berada pada kriteria efektivitas tinggi dengan persentase sebesar $62 \%$.

\section{BIBLIOGRAFI}

Afandi, Muhamad, Chamalah, Evi, Wardani, Oktarina Puspita, \& Gunarto, H. (2013). Model dan metode pembelajaran. Semarang: UNISSULA.

Arsyad, Azhar. (2014). Media Pembelajaran. jakarta: Rajawali Pers.

Gunawan, Heri. (2012). Pendidikan karakter. Bandung: Alfabeta, 2.

hifzul Muiz, Mohammad, \& Sumarni, Nani. (2020). Pengaruh Teknologi Pembelajaran Kuliah Online Di Era Covid-19 Dan Dampaknya Terhadap Mental Mahasiswa. EduTeach: Jurnal Edukasi Dan Teknologi Pembelajaran, 1(2), 153-165.

Khoriah, Aah. (2020). Pengaruh Model Pembelajaran Kooperatif Tipe Jigsaw Terhadap Motivasi Belajar Pendidikan Agama Islam Siswa Kelas X TKR SMK Islamic Centre Cirebon. Jurnal Syntax Transformation, 1(1), 1-5.

Mukson, Mukson. (2017). Pengaruh Status Sosial Ekonomi Terhadap Motivasi Belajar Mahasiswa Pendidikan Guru Sekolah Dasar Universitas Muhadi Stiabudi Brebes Tahun 2017. Syntax Literate; Jurnal Ilmiah Indonesia, 2(7), 116-129.

Mulyatiningsih, Endang. (2016). Pengembangan model pembelajaran. Diakses Dari Http://Staff. Uny. Ac. Id/Sites/Default/Files/Pengabdian/Dra-EndangMulyatiningsih-Mpd/7cpengembangan-Model-Pembelajaran. $\quad$ Pdf. $\quad$ Pada September.

Nurkarsa, Aldo Hermaya Aditia. (2020). Strategi Pemasaran pada AMIK Bumi Nusantara Cirebon. Equivalent: Jurnal Ilmiah Sosial Teknologi, 2(1), 1-5.

Putra, Putu Krisna Kusuma. (2019). Penerapan Media Internet Untuk Mendukung Pembelajaran Pada Mata Pelajaran Etika Profesi Kelas X Akuntansi Di Smk Negeri 1 Singaraja. Jurnal Pendidikan Ekonomi Undiksha, 10(2), 480-489.

Rismiyanti. (2012). Tentang WhatsApp : Pengertian, Manfaat, dan Fitur- Fiturnya yang Wajib Anda Ketahui. Jakarta: Kalam Mulia.

Rosyidah, Ida, \& Maryati, Delis Sri. (2019). INOvasi Pembelajaran SKI Berbasis Media Mobile (Studi Kasus Di Stai Al-Jawami). Tsaqafatuna, 2(1).

Silmi, Thoriq Aji. (2021). Efektivitas penggunaan Aplikasi Media Streaming youtube dalam meningkatkan hasil belajar peserta didik Mata Pelajaran PAI di Kelas XI 
Suri Triwahyuni

IPA 2 SMAN MT Bojonegoro. UIN Sunan Ampel Surabaya.

Sutikno, M. Sobry, \& Fathurrohman, Pupuh. (2010). Strategi Belajar Mengajar Melalui Penanaman Konsep Umum \& Konsep Islami. Refika Aditama: Bandung.

Trianto, M. Pd. (2010). Mendesain model pembelajaran inovatif-progresif: Konsep, landasan dan implementasinya pada Kurikulum Tingkat Satuan Pendidikan (KTSP). Jakarta: Kencana.

untuk Pembelajaran, Lembar Kegiatan Literasi Saintifik, \& Jauh, Jarak. (2020). Edukatif: Jurnal Ilmu Pendidikan. 